\title{
A encenação da competência linguística na escrita de abstracts em DaF: um estudo de caso sobre uso, função e produção de estruturas predicativas com als
}

[The staging of linguistic competence in the writing of abstracts in DaF (German as a Foreign Language): a case study on the usage, function and production of predicative phrases with als]

\author{
Júlio Matias ${ }^{1}$
}

\begin{abstract}
This paper discusses the notion of linguistic staging as applied to the field of German as a Foreign Language (DaF). We thus propose a concept of staging of linguistic competence as a strategic procedure by which the scientific academic literacy of writers is enacted in a foreign language. Through staging, learners show linguistic competence to formulate complex structures and to express routines and actions of conventionalized language in the target discourse. We hold that linguistic enacting can be expressed through specific structures as well as through processes of selection of terms. This conjecture is discussed based on the predicative use of syntagmas beginning with als, which, due to this structure's functional and semantic properties, can be seen as a means for linguistic staging. The corpus is comprised of abstracts written in German by Brazilian doctoral and master's students, and of "think aloud" protocols of the production of those texts. The data suggest that writers often find it difficult to carry out syntactic plans beginning with als and to choose the correct verbs for arguments beginning with als. Nonetheless, two strategies of linguistic staging were identified during the study: paraphrasing and accessing semantically concrete concepts before taking up abstract concepts.
\end{abstract}

Keywords: Academic discourse; linguistic complexity; writing process; language repairs; lexical access

Resumo: O presente ensaio discute a noção de encenação linguística, aplicando-a ao campo de estudos de Alemão como Língua Estrangeira (DaF). Assim, propomos um conceito de encenação da competência linguística, como um procedimento estratégico através do qual a competência científica dos escritores é representada por meio da língua estrangeira. Através da encenação, os escritores demonstram domínio linguístico para formular estruturas complexas, bem como para expressar rotinas e ações de linguagem convencionalizadas no discurso alvo. Defendemos que a Encenação Linguística pode-se manifestar através de estruturas específicas, e através de processos de seleção lexical. Essa conjectura é discutida com base no uso predicativo de sintagmas introduzidos por als, os quais, devido a suas propriedades semânticas e funcionais, podem ser vistos como um recurso de encenação linguística. O corpus é composto de abstracts

\footnotetext{
${ }^{1}$ Doutorando no Herder Institut da Universidade de Leipzig e Leitor Brasileiro do MRE/DPLP na Universidade de Colônia Email: matias.julio@uni-koeln.de
} 


\section{Matias, J. - Encenação da competência lingüística em DAF}

escritos em alemão por mestrandos e doutorandos brasileiros e de Protocolos de Pensamento em Voz Alta da produção daqueles textos. Os dados apontam uma recorrente dificuldade para completar um plano sintático iniciado por als, assim como para selecionar os verbos adequados para um argumento introduzido por essa partícula. Não obstante, duas estratégias de encenação linguística puderam ser identificadas: a paráfrase e o acesso a conceitos semanticamente concretos antes da ativação de conceitos abstratos.

Palavras-chave: Discurso Acadêmico - Complexidade Linguística - Processo de escrita Reparos de Linguagem - Acesso lexical

\section{Introdução}

Realizando uma despretensiosa busca no catálogo da DEUTSCHE NATIONAL BIBLIOTHEK (DNB) para as palavras-chave Drama e Theater, deparamo-nos com títulos tais como: Theater als Form politischer Partizipation (GUNDLACH 2012), Der Altar als Bühne (Schuler 2013), Die Welt als Drama (Dellwing et al. (ed.) 2013), Theater als kritischer Erfahrungsraum im Stoffwechsel zwischen Bühne und Musik (VAGN LID, 2011), Theater als System : eine Evolutionsgeschichte des modernen Theaters (HOFFMANN 1997), Theater als Gedächtnis: semiotische und psychoanalytische Untersuchungen zur Funktion des Dramas (SIEGMUND 1996).

Essa busca informal é ilustrativa para o recorrente emprego da estrutura $X$ als $Y$ em textos acadêmicos de diversas áreas em língua alemã, bem como para o leque de funções sintáticas e relações semânticas que ela permite. Tomando exemplarmente o resultado de nossa busca e recorrendo às artes cênicas como metáfora, observamos que um dos possíveis significados de als é designar que um determinado elemento, na esfera de todas as acepções possíveis, representa um papel selecionado, dentro de um determinado contexto. Em outras palavras, o referente designa um dos papéis que o núcleo nominal pode assumir, construindo, deste modo, um "cenário" restrito dentro do qual ele será abordado. Nesse sentido, os títulos do catálogo da DNB demonstram como o núcleo nominal "teatro" pode ser abordado sob diferentes prismas: como uma forma de participação política, como um espaço de experiência crítica, como sistema ou como memória, dentre outros possíveis.

É interessante ressaltar como a estrutura sintática é convencionada para a formulação de um elemento indispensável da própria organização textual, no caso, o 


\section{Matias, J. - Encenação da competência lingüística em DAF}

título - a porta de entrada para a interação entre leitor e texto. O título, antes do resumo, da orelha, ou da contra-capa, é o elemento que irá despertar o interesse do leitor, o qual, seletivamente, pode ou não, prosseguir com a leitura do artigo, do livro, ou decidir-se por uma palestra. É elementar que $X$ als $Y$, mais que um tipo de padrão sintático para formulação de títulos, desempenha outras funções para a realização de ações de linguagem, próprias da prática textual acadêmica, p.e. expressar julgamentos, ou formular definições. Esse fato permite caracterizar als amplamente como um recurso da linguagem comum, aplicado à reprodução da linguagem científica, ou seja, como um recurso da Linguagem Científica Comum (allgemeine Wissenschaftssprache) (cf. EHLICH 1999).

De classificação gramatical controversa, als introduz um predicativo, abrindo uma lacuna para a expansão de um grupo nominal ou para a inserção de um complemento verbal. Dentro do grupo nominal, ele pode funcionar como um atributo, excluindo-se aqui seu emprego em orações comparativas, orações adverbiais temporais ou em contextos imaginários (e.g. als ob) ou aditivos ( e.g. sowohl ... als auch).

Aproveitando o Drama como foco temático deste número, aliado ao olhar inicial sobre os possíveis papéis que uma partícula como als pode assumir para expressar ações de linguagem, o presente ensaio busca discutir um conceito transposto das artes cênicas para a análise do discurso, qual seja, o de encenação linguística. Todavia tentarei, para além da discussão, aplicar o conceito à produção do discurso acadêmico em língua estrangeira, propondo, desse modo, uma noção de encenação da competência linguística.

Esse ponto é de grande interesse para a didática do Alemão como Língua Estrangeira (Deutsch als Fremdsprache - doravante DaF). A dificuldade de falantes não-nativos, e mesmo dos próprios falantes nativos, com estruturas e modos de expressão rotinizados na linguagem acadêmica, já foi objeto de diversos estudos. Em alguns, nota-se que determinados contextos, nos quais als desempenha um papel central, não são incólumes a tais dificuldades. Nesse sentido, proponho, nas próximas páginas, investigar o modo como estruturas predicativas com als podem ser utilizadas heuristicamente na formulação de atos retóricos e de linguagem dentro da prática textual acadêmica, considerando, para tal, até que ponto tais estruturas servem como meio de encenar, mais que a linguagem, a competência linguística. $\mathrm{O}$ diferencial desta 


\section{Matias, J. - Encenação da competência lingüística em DAF}

abordagem é o cruzamento de dados textuais com dados processuais, com o intuito de obter indícios sobre a base cognitiva dessa forma de encenação linguística. Assim, serão apresentados dados empíricos de um estudo sobre o processo de escrita de abstracts de congressos, redigidos em língua alemã por doutorandos e mestrandos brasileiros. Com isso, interessa-nos saber se é possível identificar padrões de uso e produção do als predicativo nos textos produzidos, além de refletir sobre estratégias e recursos linguísticos utilizados por falantes não-nativos para concretizar o que aqui consideramos encenação.

$\mathrm{Na}$ primeira seção, será apresentado um breve panorama da aplicação do conceito de Encenação Linguística em diferentes campos de estudo. A seguir, o conceito de Linguagem Comum Científica será delineado, de modo a fornecer as bases para abordarmos funcionalmente as construções predicativas com als no contexto da produção de textos acadêmicos. Na terceira parte, será fornecido um breve quadro da tentativa de classificação gramatical de als, baseado na etimologia dessa partícula. A partir disso, na quarta parte, serão descritas, resumidamente, as funções sintáticas e algumas das várias possibilidades semânticas de als. A parte seguinte concentra-se no estudo de caso, para o qual foi utilizado um software de captura de imagem na coleta de dados obtidos por meio de protocolos de pensamento em voz alta (Think Aloud Protocols). Esses dados compõem o corpus de análise da produção autêntica dessas estruturas na língua materna (L1) e na língua estrangeira (L2).

Finalmente, retomaremos a questão da encenação à luz dos dados apresentados, buscando apontar implicações didáticas deste trabalho.

\section{Encenação Linguística}

Encenação linguística é um conceito geralmente mais aplicado que propriamente delimitado teoricamente. Se recorrermos à linguagem comum como ponto de partida para pensarmos esse conceito, encontraremos no DICIONÁRIO HOUAISS (2009: 749) as seguintes denotações: encenação como "1. TEAT espetáculo teatral, montagem, representação 4. atitude que se caracteriza pela falta de sinceridade ou por não corresponder à verdade, cujo fito é iludir ou impressionar alguém”, e do ato de encenar como "1. pôr em cena; preparar a infra estrutura necessária para levar à cena um 


\section{Matias, J. - Encenação da competência lingüística em DAF}

espetáculo esp. Teatral, montar 3. t.d. representar ('exibir em teatro, 'interpretar um personagem')".

No campo da análise do discurso, a noção de encenação linguística é aplicada na interpretação do modo como determinados papéis são representados no processo de interação entre sujeitos, dentro de um determinado contexto social, através da linguagem. Assim, diversos campos de estudo servem-se da noção de encenação linguística na investigação de temas pertinentes a questões de gênero, de consenso entre sujeitos e instituições, bem como para caracterização de atos de fala dentro do discurso propagandístico e do próprio discurso científico. Entretanto, a questão da encenação parece ainda não ter recebido a devida atenção no âmbito da produção de linguagem em língua estrangeira. Nesse sentido, o presente ensaio pretende contribuir para uma discussão do conceito de encenação linguística, analisando o modo como falantes nãonativos utilizam os recursos linguísticos dos quais dispõem na língua estrangeira, para desempenhar papéis dentro de uma dada prática discursiva - seja para apresentar-se como tecnicamente especializados, e desse modo, como pertencentes à comunidade científica, seja para mostrar-se linguisticamente competentes, e cientes das exigências pragmáticas e textuais dessa comunidade.

A noção de encenação é amplamente disseminada no campo dos Estudos de Gênero. Um exemplo é o trabalho de GotTBURGSEN (1995), que parte da premissa de que a linguagem é um sistema de produção simbólica de significado. GotTBURGSEN investiga como o gênero social é representado por homens e mulheres em anúncios de jornal publicados na seção "correio afetivo". Segundo a autora, os indivíduos, no processo de interação dentro de um contexto de situação, encenam seus gêneros conforme expectativas culturalmente determinadas (GoTTBURGSEN 1995: 259). A análise de GotTBURGSEN pauta-se pela intensidade com que palavras de um determinado campo semântico aparecem em anúncios de homens e mulheres, tanto em suas auto-representações, como nas representações do outro, a quem se procura. Como exemplo, a pesquisadora observa que palavras do campo semântico "Trabalho" são usadas mais por homens para se auto-representar, do que entre as mulheres. Inversamente, as mulheres tenderiam em seus anúncios a uma auto-representação na qual campos semânticos como "aparência" e "carisma" seriam mais reforçados. Segundo Gottburgsen, através da encenação linguística das diferenças entre gêneros, os 


\section{Matias, J. - Encenação da competência lingüística em DAF}

sujeitos reafirmam o seu pertencimento a um grupo, de acordo com parâmetros culturalmente determinados. Desse modo, no processo de interação, eles não só constroem uma imagem de gênero social e culturalmente estabelecida, como também reproduzem o discurso de diferença institucionalizado.

Um outro campo de estudo que se vale do conceito de encenação é o da Comunicação Organizacional. HABSCHEID \& KNOBLOCH (2009) introduzem a encenação linguística como um recurso de representação simbólica de consenso entre forças conflitantes dentro do ato comunicativo. Desse modo, o consenso, como construto discursivo de uma organização, serve para estabilizar relações sociais de poder, assim como para legitimar e impor decisões políticas. Esse "consenso de fachada" (HABSCHEID \& KNOBLOCH 2009: 8ss.) seria uma característica paradoxal da comunicação formal dentro de uma organização. Por um lado, existe uma relação de poder assimétrica, na qual sujeitos são coagidos a compactuar com as esferas detentoras de poder. Porém, concomitantemente, o discurso pauta-se pela constituição comunicativa de identidade, na qual cada sujeito é abordado como peça integrante e fundamental de um conjunto harmônico. Assim, o poder não é exercido explicitamente, mas sim, manifesta-se tacitamente sob a superfície de um jogo de linguagem encenado (id.). Assim, a encenação e o controle social se dão através de práticas e procedimentos discursivos (HARTZ 2009: 183).

A encenação de consenso, porém, não se manifesta somente no âmbito proposicional, mas também em práticas não-discursivas, como em cultos, conforme observa ANTOS (2009) $)^{2}$. A fim de analisar a encenação de consenso na esfera performática, ANTOS vale-se da Teoria da Mimese, de René Girard, segundo a qual a imitação, enquanto predisposição ontológica do ser humano, é decisiva tanto para a formação de grupos, quanto para o aprendizado de regras e padrões de comportamento dentro do ambiente social. Assim, o culto, enquanto um ato performático que se repete e

\footnotetext{
2 Cito no original: "Anders als ein mühsam durch Diskussion oder Diskurse entstandener Konsens beruhen viele dieser Inszenierungen aber gerade nicht auf einer inhaltlichen, d.h. propositional basierten Grundlage, sondern auf dem Selbstgenuss gemeinschaftlicher Performativität. Bei ästhetischer, rhetorischer oder ritueller Kommunikation wird der kaum greifbare, aber prägende Einfluss dieser Performativität im Allgemeinen auch zugestanden. Dennoch dominiert bei der Erzeugung von Konsens noch weithin die Vorstellung des Primats des Propositionalen vor der Performativität." (ANTOS 2009: 118).
} 


\section{Matias, J. - Encenação da competência lingüística em DAF}

se caracteriza pela imitação recíproca, reafirma e atualiza uma determinada prática coletiva no âmbito não-discursivo.

Exatos quatorze anos antes de se dedicar à análise da encenação em práticas nãodiscursivas, ANTOS já tecia considerações sobre a encenação linguística de expertise no discurso científico, desta vez recorrendo à noção de redução de contingente da Teoria de Sistemas Sociais de Niklas LUHMANN. ${ }^{3}$ O conceito de contingência designa a unidade de diferença da possibilidade e impossibilidade do real (KRAUSE 1996: 123 ). Ou, nas palavras de LUHMANN, contingentes são estados de coisas no mundo (Weltsachverhalten), que também são possíveis de outra forma (LUHMANN 1984: 217). Neste sentido, a comunicação, consequentemente a produção de discurso, precisa vincular-se à comunicação (Anschließbarkeit von Kommunikation an Kommunikation LUHMANN apud ANTOS 1995: 113). O êxito comunicativo, segundo ANTOS (1995), ou seja, a relevância da comunicação para um determinado grupo, dependeria, portanto, de padrões de sentido disponibilizados via repetição e reprodução, de modo que a alta contingência do sistema possa ser reduzida (id.). Aplicando-se ao discurso científico, isso significa que novos textos constroem-se a partir de textos anteriores, os quais estabelecem padrões discursivos replicáveis, ou o que ANTOS (1995) denomina invariâncias (Invarianzen). Sem embargo, o novo texto em si é, recursivamente, um candidato ao fornecimento de novos padrões, contribuindo, dessa maneira, para uma contínua redução da contingência dentro do sistema. Assim, "encenação linguística" refere-se à manifestação de qualquer invariância linguístico-textual que, apesar de não

\footnotetext{
${ }^{3} \mathrm{O}$ escopo e o foco do presente trabalho não permitem uma discussão aprofundada da ideia de contingente, a qual também se relaciona com o conceito de complexidade. De qualquer forma, vale ter em mente o que LUHMANN compreende por esses dois termos. Na entrada, fornecida pelo autor no Historisches Wörterbuch der Philosophie (p. 378), lê-se no primeiro parágrafo a base para a compreensao do que se chama reducao de complexidade: "Reduktion von Komplexität ist ein systemtheoretischer Begriff. Er taucht in der koginitiven Psychologie auf, um zu bezeichnen, dass ein System eine Vielzahl verschiedenartiger Umweltsachverhalte zusammenfassen und auf je einen Ausdruck bringen muß, um sie intern verarbeiten zu können." (LUHMANN: 387). A relação entre redução de complexidade, seleção e contingência encontra-se resumida no seguinte trecho da obra Soziale Systeme - Grundriß einer allgemeinen Theorie: "Komplexität in dem angebenene Sinne heißt Selektionszwang, Selektionszwang hießt hier Kontingenz, und Kontingenz heißt Risiko. Jeder komplexe Sachverhalt beruht auf einer Selektion der Relationen zwischen seinen Elementen, die er benutzt, um sich zu konstruieren und zu erhalten. Die Selektion placiert und qualifiziert die Elemente, obwohl für diese andere Relationierungen möglich wären. Dieses ,auch anders möglich sein“ bezeichnen wir mit dem tradionsreichen Terminus Kontingenz. Er gibt zugleich den Hinweis auf die Möglichkeit des Verfehlens der günstigtsen Formen." (LUHMANN 1984: 47). É importante ter em mente que ANTOS não fala em redução de complexidade, mas sim, em redução de contingência, embora alguns trechos de seu texto sugiram uma referência à redução de complexidade, se considerarmos que a contingência em si, com base na citação anterior, já pressupõe uma seleção.
} 


\section{Matias, J. - Encenação da competência lingüística em DAF}

estabelecida, encontra-se em uma relação antagônica ou intertextual com outros textos e suas respectivas invariâncias (cf. ANTOS 1996: 115ss.). O analista precisa identificar tais invariâncias linguístico-textuais, as quais não seguem um padrão obrigatório, mas podem ser reconhecidas como potenciais candidatas ${ }^{4}$. Deste modo, ANTOS (1996: 122 SS.) apoia-se na análise de meios retóricos e estilísticos para idenficar quatro esferas da encenação linguística de expertise em abstracts: 1) Comunicação interna, 2) transparência, 3 ) conhecimento factual e 4) autoridade científica.

A comunicação interna tange o hermetismo do registro, direcionado à recepção de um público técnico e especializado. Paradoxalmente, o texto não procura estabelecer uma relação interpessoal direta com o receptor. A sintaxe hermética e impessoal, aliada ao vocabulário técnico, o qual projeta o objeto em primeiro plano, selecionam os recipientes do texto.

A encenação de transparência representa o contrário da comunicação interna. Mesmo dispondo de complexidade linguística e vocabulário técnico, existe um esforço do texto em facilitar a compreensão da matéria para um público externo.

A encenação do conhecimento factual serve para demonstrar a competência técnica do sujeito. Meios para tal podem ser identificados, por exemplo, quando se aponta para uma lacuna em determinada área de estudos ou quando o sujeito acentua o modo como ele próprio está contribuindo para o desenvolvimento da área de estudos.

Finalmente, a encenação de autoridade científica, a menos relevante para o presente trabalho, caracteriza-se pelo modo como sumidades dentro de um determinado campo de estudos levantam questionamentos críticos com relação a outras posições científicas.

Considero que muitos pontos das aplicações da noção de encenação linguística acima descritas - nos Estudos de Gênero, na Comunicação Organizacional, em uma prática não-discursiva e no Discurso Acadêmico - podem ser sintetizados na abordagem de Patrick Charaudeau. Charaudeau (2010) caracteriza a encenação linguística partindo do postulado de que toda e qualquer relação social é marcada por relações de

\footnotetext{
${ }^{4}$ Cito no original: "[...] die Manifestation von jenen (sprachlich-textuellen) Invarianzen, die weder mit diachron tradierten noch mit bereits verbindlichen synchronen Muster zusammenfallen. Als sozusagen „Muster im status nascendi“ können sie aber sowohl in einem intertextuellen wie in einem oppositionellen Verhältnis zu vergleichbaren anderen Texten und deren sozial verbindlichen Invarianzen stehen." (ANTOS 1995: 115).
} 


\section{Matias, J. - Encenação da competência lingüística em DAF}

influência. O modo como essas relações são representadas dentro da linguagem baseiase em um princípio de alteridade. Para tanto, é necessário que o eu "reconheça a existência de um outro na sua diferença identitária de sujeito falante", para que possa tomar consciência de si como sujeito comunicante (CHARAUDEAU 2010: 58). A relação entre ambos os atores se dá através do ato de linguagem, que ocorre dentro de uma situação de comunicação, a qual impõe um processo de regulação interacional de acordo o grupo social ao qual se pertence. A situação comunicativa é, portanto, pautada pelo que CHARAUDEAU denomina contrato de comunicação e instruções discursivas. Desse modo, a situação de comunicação dita as normas da interação, permitindo que os sujeitos comunicantes construam uma expectativa de troca, restringindo, assim, o modo de encenação dentro do grupo social. Ou seja, a situação e as expectativas que dela emanam determinam a posição de legitimidade dos sujeitos falantes.

A legitimidade, por sua vez, exige que o sujeito falante alcance credibilidade e consiga captar o interlocutor ou o público, lançando mão de "procedimentos rituais sociolinguageiros" (CHARAUDEAU 2010: 59) codificados pelo grupo. Neste sentido, o sujeito falante busca influenciar o outro, recorrendo a estratégias discursivas, orientadas segundo quatro fatores (id.:57): 1) o modo de estabelecimento de contato com o outro e o modo de relação entre ambas as partes; 2) a construção de uma imagem do sujeito falante, a qual permita que ele seja reconhecido como uma pessoa merecedora de atenção; 3) a maneira de tocar o afeto do outro para efeitos de sedução ou persuasão, o que CHARAUDEAU chama de dramatização; 4) os modos de organização do discurso, através de uma retórica narrativa e argumentativa, que permita que o mundo seja descrito segundo os princípios de veracidade.

Esse panorama de abordagens demonstra que o conceito de encenação linguística não é elaborado numa fórmula de equivalência, mas antes circunscrito por uma série de aspectos, dentre os quais podemos destacar: 1) a reprodução ou imitação de práticas discursivas estabelecidas dentro de um grupo, as quais são mais ou menos invariáveis; 2) a representação de um papel ou de uma ação por meio da linguagem, em um determinado processo de interação, de acordo com o contexto de situação; 3) a redução da complexidade e da contingência de um sistema, por meio de seleção, conforme as exigências do contexto de situação. Um exemplo simples e prático dessa encenação dentro do cotidiano pode ser encontrado na produção rotineira de e-mails: 


\section{Matias, J. - Encenação da competência lingüística em DAF}

para fazer uma reclamação, um convite de aniversário, ou marcar um encontro formal, assumimos diferentes papéis ao transitar por cada esfera de interação e de discurso. Esses papéis são transmitidos ao recipiente através de recursos linguísticos, por meio dos quais os recipientes, por sua vez, criam uma determinada imagem de nós, como atores convidam, reclamando, marcam horários etc.

Se transpormos esse cenário para o contexto de produção escrita em língua estrangeira, é plausível assumir que a encenação linguística deva ocorrer em dois níveis: primeiro, no nível da competência textual, supostamente desenvolvida na própria língua materna e de fundamental importância para a o trânsito entre diferentes esferas discursivas e de interação; e segundo, no nível da competência linguística, no qual o falante apresenta (ou mesmo representa) o domínio que possui da língua-alvo, no âmbito lexical e gramatical. A inter-relação entre esses dois níveis é evidente principalmente em casos nos quais os falantes, apesar de não disporem de conhecimentos linguísticos suficientemente avançados, precisam produzir textos complexos, que exigem o emprego das chamadas estratégias de transformação do conhecimento (Knowledge Transforming) (SCARDAMALIA \& BEREITER 1987), como no caso dos textos acadêmicos. Ou seja, na produção do discurso acadêmico em língua estrangeira, a legitimidade (no sentido de CHARAUdEAU 2010), o domínio de invariâncias linguístico-textuais (no sentido de ANTOS 1995), e afirmação de pertencimento ao grupo, são intermediadas pelo modo como o aprendiz "imita" (ANTOS 2009) a linguagem acadêmica na L2, bem como pelo modo como ele faz uso de todo o seu conhecimento textual, lexical e gramatical para assegurar o êxito comunicativo.

Neste sentido, o presente trabalho busca 1) refletir sobre critérios que sirvam para identificar contextos de encenação linguística em língua estrangeira, 2) buscar uma base cognitiva para a encenação linguística através de evidências de base processual, 3) tecer considerações sobre o modo como estruturas sintáticas específicas podem servir de recurso à encenação da competência linguística em língua estrangeira.

Tomando o primeiro ponto, um critério dedutivo para se medir o nível de encenação pode ser visto na complexidade linguística das estruturas produzidas. A complexidade linguística pode ser avaliada, dentre outros critérios, pela utilização de orações paratáticas ou hipotáticas, de itens lexicais menos frequentes na língua e a formulação de grupos nominais complexos, contendo elementos opcionais. A 


\section{Matias, J. - Encenação da competência lingüística em DAF}

complexidade linguística presta-se como um critério para mensurar a encenação pelo fato de permitir que o escritor demonstre, na língua estrangeira, o seu domínio do sistema linguístico e sua capacidade de estabelecer relações lógicas sofisticadas. Este ponto pode ser endossado pelo estudo de FEHRINGER \& FRY (2007), onde a opcionalidade é analisada como um critério de complexidade linguística:

We suggest that optionality, as conceptualized in this study, could play a role in the ostentation of one's language prowess. Speakers could thus demonstrate how successfully they could manage the mental resources available to them. (FEHRINGER \& FRY 2007: 507).

Contudo, defendemos que a compreensão da encenação em língua estrangeira exige o cruzamento de dados textuais com dados processuais. Só assim é possível observar em que medida os escritores conscientemente manipulam sua expressão para a encenação linguística nos termos aqui considerados. Ademais, o olhar sobre o processo permite identificar, indutivamente, critérios, e estratégias comunicativas (cf. MANCHÓN \& ROCA DE LARIOS 1999) que se prestem à encenação.

Esses aspectos serão melhor desenvolvidos quando da apresentação do estudo de caso, no qual estudantes brasileiros produziram abstracts de conferência em alemão como língua estrangeira. Do ponto de vista empírico e metodológico, abstracts são interessantes não só para o reconhecimento dos quatro tipos de encenação esboçados por ANTOS (1995), quais sejam, comunicação interna, transparência, conhecimento factual e autoridade científica - como também para a análise de material linguístico, característico de registros acadêmicos, através do qual a encenação da competência pode se manifestar, como, por exemplo, no uso de grupos nominais complexos, tokens menos frequentes, nominalizações etc. Do ponto de vista processual, abstracts podem ser produzidos em uma seção de coleta de dados de pensamento em voz alta, o que permite observar como os escritores, mais ou menos conscientemente, encenam o discurso na língua-alvo. Outro aspecto são as implicações didáticas que um conceito de encenação pode proporcionar. Defendo aqui que a encenação, no contexto de aprendizado de língua estrangeira, pode ser vista como uma estratégia positiva, através da qual os escritores, nos limites de sua capacidade linguística, buscam representar o papel de integrantes da comunidade científica, formulando uma qualidade de enunciados, mais ou menos bem sucedidos. 
Matias, J. - Encenação da competência lingüística em DAF

\section{Linguagem Comum Científica}

A Linguagem Comum Científica (EHLICH 1999) converte o material linguístico da linguagem cotidiana em rotinas e expressões convencionalizadas, por meio das quais a transmissão do conhecimento científico é retoricamente elaborada. Um exemplo é o verbo sehen: enquanto na linguagem comum este designa a percepção óptica (ex. a), na linguagem técnica, ao reger um complemento introduzido por als, ele expressa um julgamento (ex. b) (cf. FANDRYCH 2004, GRAEFEN 2004):

Ex.: 1a) Wenn Sie in letzter Zeit immer mehr blaue Handtücher, Schüsseln, Autos und Hemden gesehen haben, sind Sie nicht allein. Die Zeit, 18.11.19995

1b) Die Oesterreichische Nationalbank (OenB) sieht als Konsequenz der Wirtschaftskrise in Osteuropa keine existenzielle Gefahr für heimische Finanzinstitute. Die Zeit, 05.07.2009

A Linguagem Comum Científica seria, laconicamente, aquilo que se encontra entre um termo técnico e outro (EHLICH 1999: 8). Ela é fundamental tanto para a compreensão quanto para a produção textual-discursiva dentro da comunidade científica. Trata-se de uma linguagem interdisciplinar, através da qual são construídas não só rotinas retóricas e textuais ${ }^{6}$, como também em relações sintáticas usuais em gêneros acadêmicos. Contudo, o domínio dessas rotinas e estruturas pode colocar entraves à produção dessa linguagem, especialmente para falantes não-nativos. GRAEFEN (1999: 232) discute o seguinte exemplo de uma construção errônea na língua estrangeira, no qual há um equívoco no emprego do verbo que seleciona o complemento introduzido por als:

Ex.: 2) Als eine weitere Untergliederung der Funktionswörter stellen sich als Fügewörter die Präpositionen und die Konjunktionen heraus.

A análise de GRAEFEN foca-se no uso inadequado do verbo herausstellen, sem, no entanto, considerar que, na oração, a construção com als é utilizada duas vezes e de

\footnotetext{
${ }^{5}$ Os exemplos cuja fonte é o Die Zeit foram extraídos do corpus DWDS. Outros exemplos, referem-se a um corpus de referências construídos no âmbito deste projeto, baseado no trabalho de YAKHONTOVA (2002). É um corpus de referência alemão-português, constituído de 80 abstracts, extraídos de cadernos de resumos das áreas de sociologia, filosofia, literatura e linguística.

${ }^{6}$ Se pensarmos, por exemplo, na estrutura retórica de introduções por meio de moves proposta por SWALES (1996).
} 
Matias, J. - Encenação da competência lingüística em DAF

maneira ambígua (Die Präpositionen stellen sich als weitere Untergliederung und als Fügewörter heraus.) Consideremos, em todo caso, que als, em um momento, seja empregado como complemento verbal, e posteriormente, como adjunto adnominal, no qual uma informação complementar, em função atributiva, é fornecida (die Präpositionen und Konjunktionen als Fügewörter). Defendemos que a formulação de duas predicações com als (em uma oração de dezesseis palavras) e a inadequação do verbo utilizado no exemplo de GRAEFEN poderia caracterizar um modo de encenação da competência linguística. O que torna essa encenação visível são justamente as falhas que ela apresenta, quando da tentativa de maximizar o condensamento de informação. Ora, als permite ampla variedade de funções sintáticas e relações de significado, como será demonstrado na seção 4. Ao mesmo tempo, ao tentar reproduzir determinadas invariâncias em língua estrangeira, o autor de texto acadêmico pode, consciente ou inconscientemente, recorrer a expressões não condizententes com aquelas textual e linguisticamente estabelecidas na língua-alvo. São, portanto, potenciais candidatas do ponto de vista do aprendiz, mas irrealizáveis na língua-alvo. Isso ocasiona um erro. Todavia, ainda criando uma "invariância errônea", o aprendiz "põe em cena" o seu conhecimento linguístico através da complexidade de suas escolhas, seja, por ex., utilizando tokens mais ou menos frequentes, construindo grupos nominais complexos ou lançando mão de hipotaxe (cf. FEHRINGER \& FRY 2007).

Entretanto, o emprego do als predicativo em outros contextos que não os complementos verbais ainda não recebeu a devida atenção seja em estudos sobre a Linguagem Comum Científica baseados em corpora, seja no âmbito da produção de textos escritos em DaF. Faz-se, portanto, conveniente descrever outros contextos de ocorrência desta estrutura, partindo, para tanto, de sua controversa classificação gramatical no alemão.

\section{Classificação gramatical e etimologia de als}

A classificação de als é alvo de controvérsia tanto nas gramáticas quanto na literatura especializada. Conforme FlaAte (2007) e Thurmair (2001) em seus respectivos mapeamentos, observa-se que essa partícula pode ser compreendida como preposição, conjunção, conjunção preposicional ou conjuntor, dentre várias outras classificações. Os 


\section{Matias, J. - Encenação da competência lingüística em DAF}

sintagmas introduzidos por als podem ser classificados como predicativos, complementos, adjuntos, advérbios, atributos predicativos ou preposições adverbiais, para citar somente alguns termos. Com efeito, o que se pode é apontar algumas classificações que não se aplicam a als.

Als não pode ser compreendido como uma preposição, por não reger um caso condição indispensável para essa classe verbal (THURMAIR 2001:43ss., EGGINS 2006: 192). Como conjunção, por outro lado, somente o significado temporal de als é abarcado, sem que outros contextos de uso sejam contemplados. Em als convergem características de diferentes classes funcionais, o que lhe atribui uma ampla versatilidade semântica na construção de relações sintáticas (THURMAIR 2001: 43ss). Nesse sentido, EGGINS (2006:193) propõe uma designação genérica de als como um adjuntor (Adjunktor) e THURMAIR, por sua vez, como juntor. No presente trabalho, adotaremos a nomeclatura de THURMAIR.

Diacronicamente, als é uma partícula de comparação derivada das formas als, alse, alsô "ebenso" do Alto-Alemão Médio, a qual consiste em uma redução de also. Also, por sua vez, é composto pela forma não flexionada all, a qual, como adjetivo ou advérbio, possui uma denotação simbólica (cf. HoFFMANN 2003), e so, o qual exprime uma relação de dêixis. Desse modo, also significa "ganz so, ganz genau so" e seria, segundo BÜHRIG (1993), a contra-parte do latim ergo. Deste modo, also enunciaria uma paráfrase:

Mit also fordere der Sprecher den Hörer auf, bestimmte Teile einer anschließenden Äußerungseinheit hinsichtlich einer vorherigen Äußerungseinheit als "referenzidentisch" zu interpretieren und somit die beiden Äußerungseinheiten als "Paraphrasen" von einander anzuerkennen. (BÜHRIG 1993: 236)

No caso de also, a tonicidade recai sobre o componente dêitico, cuja intensidade está diluída em als (THURMAIR 2001: 93ss.). Ainda assim, é possível observar em als a expressão de uma relação parafrásica em casos nos quais essa partícula possui função adverbial ou adnominal, estabelecendo uma relação de equivalência entre dois elementos. Entretanto, a expressão de um julgamento ou um juízo é reforçada pela forma não flexionada $a l$, conforme escreve BÜHRIG:

Die nennende Prozedur "al" geht auf eine Bewertungsoperation des Sprechers zurück, die nach einer Auswahl bestimmter Elemente der Vorstellung bzw. des Gewußten eine Gemeinsamkeit zwischen bestimmten, und, da Flektionsmerkmale fehlen, noch zu 


\section{Matias, J. - Encenação da competência lingüística em DAF}

verbalisierenden Elementen der Vorstellung bzw. des Gewußten einer anderen Klasse konstatiert (BÜHRIG 1996: 244).

Essa posição é compartilhada por GRAEFEN (1999, 2004) para quem um verbo transitivo, que expressa uma ação ou um processo, passa a exprimir um julgamento se complementado por als, como no exemplo de sehen anteriormente mencionado (GRAEFEN 1999: 228).

\section{Construções predicativas com als: aspectos semânticos e funcionais}

Estruturas atributivas introduzidas por als apresentam uma grande versatilidade semântica e funcional. Por esta razão, elas podem ser encontradas em textos científicos em variados contextos de ação retórica, seja na formulação de títulos - como demonstrado na introdução deste ensaio - seja na elaboração de definições ou na redução do escopo de compreensão de um determinado elemento. Isso é possível pelo fato de als poder exprimir diferentes significados conforme a sua função sintática. Por esta razão, é plausível assumir que estruturas introduzidas por als potencialmente representam uma estratégia heurística para encenação linguística do discurso acadêmico especialmente em língua estrangeira.

THURMAIR (2001:46) resume as funções sintáticas de als em três pontos:

a) Juntor comparativo: em estruturas comparativas, introduzindo sintagmas ou orações, em comparações irreais e após zu e genug;

b) Juntor para expressão de uma relação de predicação preposto ao grupo nominal (ou outros grupos);

c) Subjuntor, temporal e em contextos específicos.

No contexto didático, aplicações de als para além do uso comparativo e temporal são superficialmente tratadas, sendo apresentadas timidamente em alguns materiais didáticos de nível avançado, como, por exemplo, na Grammatik mit Sinn und Verstand de RUG \& TOMAZSEWSKI (2009). Por esta razão, e pelo fato de estruturas comparativas serem raras em nosso corpus, essas serão consideradas apenas perifericamente. 
Matias, J. - Encenação da competência lingüística em DAF

Em contextos de uso predicativo, als deixa-se sintetizar como uma small clause (SC) na fórmula proposta por FLAATE (2007:1):

[scNP als XP] onde X = N, A, P, Adv

A partir dessa fórmula, podemos, respaldados em BüHRIG (1996:239ss.), identificar à esquerda de als um Vorfeld ou Tema, e à direita, um Nachfeld ou Rema. Assim, als forma a base funcional para a integração ou expansão de elemento do campo simbólico, no caso, um substantivo, através de um procedimento sintático (HOFFMANN 2003: 27).

A diferenciação semântica do uso predicativo de als a ser apresentada não tem a pretensão de ser exautiva e leva em consideração fatores relevantes para a discussão dos dados textuais. Questões pertinentes, por exemplo, ao emprego de casos em estruturas introduzidas por als não serão tratadas. Para uma abordagem completa e aprofundada, recomenda-se, portanto, os trabalhos de FlaAte (2007), EgGINS (2006) e THURMAIR (2001). As três autoras adotam abordagens distintas para categorização das funções sintáticas de als e os seus possíveis significados. Para a presente investigação, tentaremos resumir os pontos relevantes do trabalho de cada uma delas, tendo consciência de divergências nas classificações propostas.

Para todos os casos aqui tratados, sintagmas introduzidos por als serão vistos como atributos predicativos, ou seja, que designam uma qualidade temporária, válida no momento da enunciação (ThURMAIR 2001: 55). Assim, é de se notar que als não exprime uma qualidade, como o faz wie (p. ex. Er spricht wie ein Muttersprachler), mas sim uma função desempenhada por um determinado ator em um determinado momento (p.ex. Er spricht als Muttersprachler):

Bei der mittels als fokussierten Funktion oder Rolle handelt es sich um eben jenen "Aspekt" des Bezugsreferenten, welcher im jeweils vorliegenden Kontext bedeutsam ist. Hierin manifestiert sich die residual-(aspekt)deiktische Qualität von als. Dabei akzentuiert als auch im hier vorliegenden "funktional-selektiven" Gebrauch das Andersartigen im Identischen: Mithilfe des als-Adjunkts wird der Bezugsrefent in einer seiner vielen Identitäten abgeschattet; als leibhaft gegebene Gestalt ist er in dieser Abschattung seiner Identität der gleiche, in seinem verschiedenen ihm zugeschriebene Funktionen ist er jedoch ein anderer. (EGGS 2006: 186ss.)

Als em si, por meio de seu uso funcional-seletivo, é uma estrutura empregada que serve para a redução de contigente, no que o falante elege as interpretações do referente 


\section{Matias, J. - Encenação da competência lingüística em DAF}

que serão encobertas. Isso imprime à semântica de als um caráter metafórico. Relembrando a teoria de LAKOFF \& JOHNSON (1980), o sistema conceptual do ser humano - do modo como pensamos e agimos - possui, fundamentalmente, natureza metafórica (LAKOFF \& JOHNSON 1980: 4). Por meio de metáfora, os seres humanos mapeiam um domínio conceitual em um outro domínio distinto, de modo que ela ressalta ou destaca a acepção de um conceito (LAKOFF \& JOHNSON 1980: 10). Ao realizar essa focalização, a metáfora oculta outros aspectos inconsistentes com a metáfora, que se tornam, assim, irrelevantes para a transmissão do enunciado. Inclusive, é interessante notar como o uso de als torna mais explícita a sistematicidade da metáfora passível de ser estabelecida entre dois conceitos. Tomemos, no caso, as estruturas de algumas metáforas conceptuais que LAKOFF \& JOHNSON apresentam proposicionalmente (por ex., ideas are people, ideas are plants, ideas as products). Substituindo-se o verbo de ligação por als (as, no inglês), percebe-se que as estruturas adquirem maior transparência figurativa, que podem ser parafraseadas por termos como "na função de", "na acepção de", "consideradas como" etc.

Em termos gerais, FlaATE e THURMAIR identificam três funções sintáticas abrangentes para sintagmas introduzidos por als: complemento verbal (Verbselegierte als-Ergänzungen), adjunto adnominal (Adnominale) e adjunto adverbial (Adverbiale). Já a nomenclatura de EGGINS orienta-se pela relação direta ou indireta que é estabelecida entre o referente e o predicativo. Na função de complemto verbal e adjunto adverbial, existe entre als e o referente uma relação indireta, mediada por um verbo. No caso do adjunto adnominal, e em alguns contextos adverbiais, é estabelecida uma relação direta entre o sintagma introduzido por als e o elemento por ele caracterizado.

\subsection{Complemento verbal}

A utilização de verbos de elocução, cuja valência exige um complemento com als (por ex., sich zeigen/präsentieren als, etwas verstehen als, etwas als etwas ansehen, etwas beschreiben als, etwas bezeichnen als, etwas dient als) pode ser interpretada como um recurso para reproduzir invariâncias linguísticas associadas a determinadas metáforas ou 


\title{
Matias, J. - Encenação da competência lingüística em DAF
}

figuras de elocução dentro da linguagem comum científica (c.f. FANDRYCH 2004) (Tab.1).

\author{
kritische Auseinandersetzung Beschreiben und Darstellen \\ $\mathrm{x}$ wird als $\mathrm{y}$ gesehen, betrachtet $\mathrm{x}$ wird als y beschrieben/dargestellt \\ Raumbezogenes Handeln Erwähnen \\ $\mathrm{x}$ stellt sich als $\mathrm{y}$ heraus $\mathrm{x}$ wird als $\mathrm{y}$ genannt \\ Forschungshandeln Sprachlich fassen, definieren \\ $\mathrm{x}$ lässt sich als y analysiert $\mathrm{x}$ wird als y bezeichnet/verstanden
}

Tab. 1. Atos de linguagem e verbos de elocução com als-predicativo (extraído e adaptado de FANDRYCH 2004)

Assim, na língua estrangeira, pode-se recorrer a tais verbos para apresentar e representar o conhecimento linguístico pertinente à utilização adequada de operadores discursivos. O uso de als como complemento verbal corresponde aos casos em que GRAEFEN (1999) chama a atenção para problemas de regência ocasionados pela seleção de um verbo inadequado. A dificuldade dos aprendizes seria, portanto, principalmente semântica, na formulação de um julgamento implícito. GRAEFEN (2004) observa que verbos transitivos diretos, como sehen, verstehen, darstellen etc., expressam uma atividade ou processo. Quando regem o juntor als, eles exprimem um julgamento implícito, ou, conforme FLAATE (2007: 66), uma estimativa dentro de uma escala entre percepção e interpretação:

Ex.: 3) Man kann es nach Flusser als "elektronisches Gedächtnis" betrachten (...). [Sociologia/TA1]

4) Literatur als Sprach-Welt kann als eigenständige Wissensordnung mit eigenen Regeln angesehen werden. [Literatura/TA5]

Isso torna a predicação com mais modalizada, se comparada à utilização de um verbo de ligação (THURMAIR 2001: 58). O exemplo b seria bem mais assertivo se tivesse sido formulado como Literatur als Sprach-Welt ist eine eigenständige Wissensordnung mit eigenen 


\section{Matias, J. - Encenação da competência lingüística em DAF}

Regeln. Desse modo, o falante toma cautela em relação à formulação da proposição, e nisso utiliza um verbo regente de als como hedge. O complemento verbal com als é sintaticamente obrigatório, ou seja, a não-utilização do mesmo acarreta má formação gramatical (THURMAIR 2001: 59). Ainda no exemplo b, no entanto, há uma predicação opcional expressa no sujeito da oração, também composto por uma estrutura com als. Neste caso, trata-se de uma função adnominal de als.

\subsection{Adjunto Adnominal}

Na função de adjunto adnominal, os predicativos com als ocorrem em um contexto exclusivamente nominal, sendo, portanto, independentes do restante da oração (FLAATE 2007: 66) e, consequentemente, do verbo (THURMAIR 2001: 50) Desse modo, apresentam-se como componentes opcionais do grupo nominal (cf. FEHRINGER \& FRY 2007):

Ex.: 5) Der Vortrag geht von der Bedeutung der Freiheit als Ausgangspunkt ethischer Überlegungen aus. [Filosofia/TA10]

Nesse exemplos, o als predicativo expande atributivamente o significado de um nome superordenado, com o qual não é estabelecida uma relação de equidade referencial. Segundo FlaATE (2007: 122), é expressa uma relação semântica assimétrica entre os elementos que ocupam as posição temática e remática, especialmente em casos nos quais, através de um nominalizações, o núcleo substantivo é tornado abstrato, como no exemplo:

Ex.: 6) Die Entlarvung des Generals als ordentlicher Drahtzieher des Aufstandes (DUdEN 1998, 742 apud. EgGINs 2006: 232)

EGGINS observa que, contudo, a regência nominal advém factualmente do verbo, o que abre a possibilidade de esses contextos serem interpretados como formas adverbiais:

Ex: 7) Der General wurde als eigentlicher Drahtzieher des Aufstands entlarvt. (DUdEN 1998, 742 apud. EgGs 2006: 233) 


\section{Matias, J. - Encenação da competência lingüística em DAF}

Além disso, als denota em contexto adnominal, o desempenho de um papel, de uma função ou o pertencimento a um grupo - o que EGGS (2006:186) descreve como o uso seu funcional-seletivo:

Ex.: 8) Literatur als Wissensordnung, Literatur und andere Wissensordnungen [Literatura/TA6]

A caracterização adicional, formulada através do grupo nominal introduzido por als, expressa a seleção de uma possível função ou papel do elemento a que se refere. Um exemplo são frases como "Ich als Student", "Sie als Brasilianerin”, “Als Frau + Verb”. São casos nos quais als deixa-se reformular como "x no papel de y", "x na acepção y", "x na função y", "x como parte de y", "x como membro integrante de y". Essa função pode ser encontrada especialmente em títulos, conforme demonstrado na introdução deste ensaio.

\subsection{Adjunto Adverbial}

A classe de als predicativos em função adverbial é a mais livre e mais complexa. Por um lado, eles podem funcionar como um complemento verbal opcional, admitindo o sentido de um advérbio de modo ou instrumento, como na frase er arbeitet als Koch (FlaAte 2007: 65). Nesses casos, os predicativos com als são vistos como complementos livres (freie Angaben) ou adverbiais livres (freie Adverbiale) (EGGINS 2006: 195).

Por outro lado, eles podem completar um nome, deixando-se reformular por um advérbio de tempo, de causa, condição ou mesmo concessão, como nos exemplo:

Ex: 9) Der Mensch als "animal symbolicum" erfasst 'Welt', 'Wirklichkeit' je schon durch das Medium der Sprache. [Filosofia /TA1] $=[$ Da der Mensch ein animal symbolicum ist, erfasst er Welt, Wirklichkeit (...).]

Ex.: 10a) Pia als Ärtztin hat das nicht gewusst!? Das ist ja wirklich unglaublich. (EGGINS 2006:187)

Obwohl Pia Ärtztin ist, hat sie das nicht gewusst!? Das ist ja wirklich unglaublich (ID.) 


\section{Matias, J. - Encenação da competência lingüística em DAF}

Ex: 10b) Als Ärtztin im Schichtdienst auf der Intensivstation hat man es wirklich schwer. (EGGINS 2006:187)

Wenn man Ärtztin im Schichtdienst auf der Intensivstation ist, dann hat man es wirklich schwer. (id.)

Nestes casos, em que o predicativo com als pode ser parafraseado em uma oração hipotática, EGGINS reconhece uma qualidade argumantativa implícita de als (EGGINS 2006: 225).

O objetivo desse breve resumo de algumas características semânticas e funcionais de als foi ilustrar a diversidade de relações complexas que podem ser condensadas por meio de três letras. Essa versatilidade semântica e sintática faz com que als se revele como um recurso linguístico eficiente para a encenação tanto linguística quanto da competência linguística, pois os aprendizes tentam "imitar" expressões da linguagem científica comum que se valem de als, as estruturas com als implicam em diversos contextos uma redução de contingente, além de permitir a relação entre dois referentes formulados com alta complexidade linguística. Em vista disso, esta predicação é um meio conveniente de demonstrar o domínio de estruturas linguística e cognitivamente complexas na segunda língua.

Neste ponto, perguntamos-nos: o que os dados processuais podem nos dizer quanto a essa encenação? Quais dificuldades os autores de escritos acadêmicos encontram na formulação de tais estruturas? Que estratégias eles/elas empregam para encenar a linguagem acadêmica? Em que medida eles/elas têm consciência dessa encenação? A seção seguinte toca tais questões.

\section{A produção de estruturas predicativas com als - um estudo de caso}

Nesta seção, serão investigados processos cognitivos envolvidos na produção de estruturas predicativas com als através de um estudo de caso realizado com falantes de alemão nativos e não-nativos. Os dados a serem apresentados consistem em uma amostra de um estudo empírico realizado com mestrandos e doutorandos alemães e brasileiros de quatro áreas das ciências humanas (literatura, filosofia, linguística e 


\section{Matias, J. - Encenação da competência lingüística em DAF}

sociologia). Os dois grupos, cada qual com seis alemães e sete brasileiros, receberam a tarefa de redigir um resumo em alemão, entre 300 e 400 palavras, para a participação em um congresso de suas respectivas áreas de estudos. Os participantes brasileiros deveriam ter pelo menos o nível B2, e, principalmente, ter tido experiência na recepção e produção de textos acadêmicos em português e alemão. A experiência na submissão de resumos e participação em congressos era desejável, mas não um critério de exclusão.

Os resumos foram escritos em um Laptop Macintosch OS Versão 10.5.8, em condições de pensamento em voz alta (Think Aloud - TA), e documentados com o auxílio do software de captura de tela Camtasia. As verbalizações foram áudiodocumentadas com o microfone interno do computador.

O primeiro procedimento na análise dos dados foi contabilizar o número de ocorrências de estruturas predicativas com als nos abstracts redigidos por cada um dos grupos. A tabela 2 resume esses números em valores absolutos. Ainda que a amostra seja insuficiente para uma análise de variação com eventual significância, observa-se entre os brasileiros um valor médio um pouco maior na utilização de estruturas aqui tratadas $(\bar{x}=3.14, \sigma=2,26)$ do que entre os alemães $(\bar{x}=2.16, \sigma=2,4)$. Em média, os informantes alemães produziram 15,6 frases, de modo que o als predicativo seria utilizado a cada sete. Os brasileiros escreveram uma média de 12,4 frases, de modo que o als-predicativo apareceria a cada quatro, portanto, com maior frequência.

Seria isso um indício da utilização de als como estratégia heurística? O uso de als pode ser apontado como um recurso de encenação da competência linguística? Ainda não é possível responder. Em todo o caso, os dados permitem observar alguns padrões de frequência dentro das áreas de estudo, independente do grupo. A tabela 2 demostra que o maior número de frequências das estruturas estão nas áreas de Literatura e Sociologia. Embora uma série de fatores possam influenciar esse número de ocorrências - por ex., preferências individuais, nível de proficiência, maturidade do trabalho de pesquisa, priming etc. -, tais números sugerem as preferências linguísticotextuais dos respectivos campos de estudo. 
Matias, J. - Encenação da competência lingüística em DAF

\begin{tabular}{llllll}
\hline$D E(n=6)$ & Área & $L 1(D T)$ & $B R(n=7)$ & Área & $L 2(D T)$ \\
\hline Antje & Linguística & 2 & Bob & Sociologia & 4 \\
Djaho & Etnologia & 1 & Carlos & Sociologia & 1 \\
Elise & Literatura & 7 & Cris & Literatura & 5 \\
Hans & Política & 0 & Dani & Sociologia & 7 \\
Karolin & Política & 2 & Pedro & Filosofia & 1 \\
Karsten & Sociologia & 1 & Renato & História & 2 \\
& & & Sonia & Sociologia & 2 \\
& & & & & 22 \\
\hline
\end{tabular}

Tab.2. Ocorrências de als nos textos produzidos em condições experimentais (valores absolutos) Legenda: DE: escritores alemães - DT: Alemão - L1: Língua materna - L2: Língua estrangeira

Com relação à distribuição, os brasileiros utilizaram, em números absolutos, três vezes mais construções com als em função adverbial do que os alemães. Dessas construções, dois terços foram formulados na voz passiva, ou seja, als aparece entre os brasileiros em maior frequência em formulações impessoais e modalizadas, funcionando como um hedge. Qualitativamente colocam-se, agora, outras questões pertinentes 1) ao grau de complexidade e de acurácia dessas estruturas, e 2) às estruturas de pensamento por trás da produção dessas construções. Elas apresentam algum tipo de dificuldade para as autoras dos textos? Quais estratégias são utilizadas para produzi-la? Os participantes têm consciência da ação encenatória? Como as autoras dos textos, enfim, formulam verbalmente a encenação?

Compreende-se como Formulação um processo mental, por meio do qual atribui-se uma representação conceptual, forma e estrutura linguística (LEVELT 1993, Kesseling 1993, PeChmann 1994, Wrobel 1995). Segundo o modelo de Levelt (1993), a Formulação ocorre a partir de uma conceitualização em um nível não-verbal, o qual designa uma intenção comunicativa. Uma vez disponível a representação 


\section{Matias, J. - Encenação da competência lingüística em DAF}

conceptual, o falante seleciona lemmas de seu léxico mental, os quais serão codificados fonológica, sintática e - no caso da escrita - grafemicamente (cf. WROBEL 2002).

Especialmente neste caso, a formulação pode ser fluente - com pausas $<3 \mathrm{~s}$, sem dificuldades, praticamente automática - ou não-fluente. Neste último caso, a formulação caracteriza-se por pausas longas ou rupturas, nas quais os autores de textos podem dar início a reparos, como reformulações, paráfrases, substituições, inserção de elementos, ou mesmo, reconceptualizar a mensagem original. Assim, uma formulação não-fluente pode ser o resultado de esforços na resolução de um problema, ou mesmo a tentativa de aprimoramento de um conteúdo já formulado.

De acordo com SCHILPEROORD (1996: 9), pausas sinalizam processos cognitivos envolvidos na mudança de estados de atenção. Nesse sentido, elas possuem três funções principais: 1) a produção de novos incrementos, ou seja, sequências linguísticas que se aglutinam ao conteúdo já produzido; 2) atualização do conteúdo na memória de trabalho, e 3) monitoramento. Nesse sentido, as pausas podem apontar para processos de planejamento, acesso lexical, leitura do texto já produzido ou dificuldades de formulação. Conforme sua duração e a localização, as pausas desenham um quadro das dificuldades encontradas durante e produção de uma determinada estrutura, além de permitirem identificar vestígios da aplicação de estratégias para solução dessas dificuldades. Relevantes para o presente estudo são, sobretudo, as pausas que ocorrem dentro de uma oração. Pausas antes de parágrafos, ou no início de uma oração não serão, portanto, consideradas.

Pausas motivadas por processos de monitoramento podem ser acompanhadas por reparos. Os falantes tendem, de modo geral, a reformular trechos do enunciado quando a expressão ideal ou apropriada não é encontrada, isto é, quando determinadas regras de boa formação do enunciado não são atendidas (cf. PECHMANN 1994:100).

Na comunicação oral, reparos são abordados como estratégias comunicativas na realização de mudanças de estrutura (structures shifts, segundo ENKVIST \& BJÖRKLUND 1989), ou, na comunicação escrita, de estratégias de reestruturação (ROCA DE LARIOS et al. 1999).

A seguir, serão apresentados quatro exemplos, nos quais estruturas com alspredicativo foram formuladas em resumos de conferência nas L1 e L2 alemão. Para tanto, os processos de escrita documentados com auxílio do programa Camtasia foram 


\section{Matias, J. - Encenação da competência lingüística em DAF}

transcritos em formato de partitura no programa EXMARaLDA (Fig.1). Com base na transcrição, foi desenvolvido um sistema de notação, o qual tenta representar graficamente a construção da oração. Assim, procurou-se ilustrar a incrementalidade da produção de linguagem escrita, a não-linearidade do processamento de grupos nominais complexos, alternativas rejeitadas e conceitos ativos na memória de trabalho. Os códigos adotados estão representados na Fig 1.

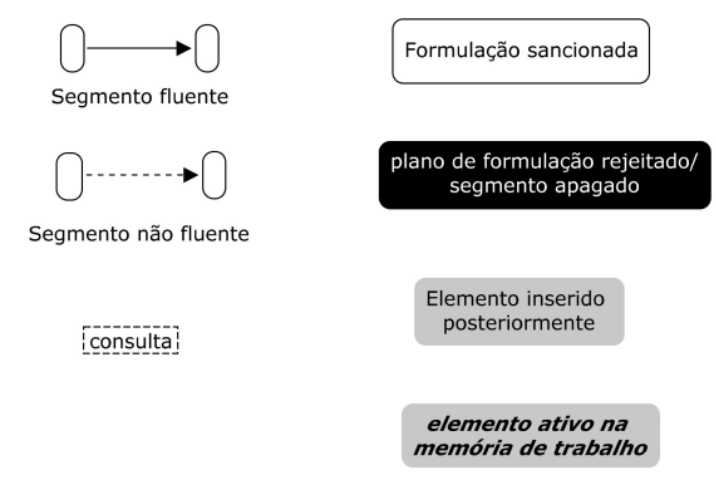

Fig 1. Legendas: notação gráfica (esq.) e transcrição (dir.)

\section{Alemão L2}

\section{Caso 1}

In diesem Sinne wird die Primatthese Luhmmans, nach der funktionale Differenzierung stratifizierte Differenzierung als primäre Differenzieungsform der Gesellschaft ersetzt hat, häufig als Synonym einer Auflösung eines Begriffes strukturierter sozialen Ungleichheit wahrgenommen.

Interpretamos o caso acima como um exemplar de encenação de comunicação interna (ANTOS 1995). Provavelmente, essa sentença é uma das mais, se não a mais hermética de todos os textos produzidos no grupo brasileiro. Tal hermeticidade é percebida na pressuposição de que o receptor tenha um mínimo de conhecimento dos termos apresentados, na densidade atributiva da formulação, observável em elementos sintaticamente opcionais, como a oração relativa, e na impessoalidade, expressa pela voz passiva. O núcleo propositional die Primatthese Luhmmans, além de ser explicado por uma oração não-restritiva, é relacionado com um grupo nominal, composto de uma 


\section{Matias, J. - Encenação da competência lingüística em DAF}

cadeia de três genitivos, que, sendo introduzida por als, funciona como argumento do verbo. Neste exemplo, como em dois outros já comentados, als aparece duas vezes. Um olhar sobre a representação do processo de escrita demonstra, contudo, que o autor enfrentou dificuldades na seleção do elemento referenciador:

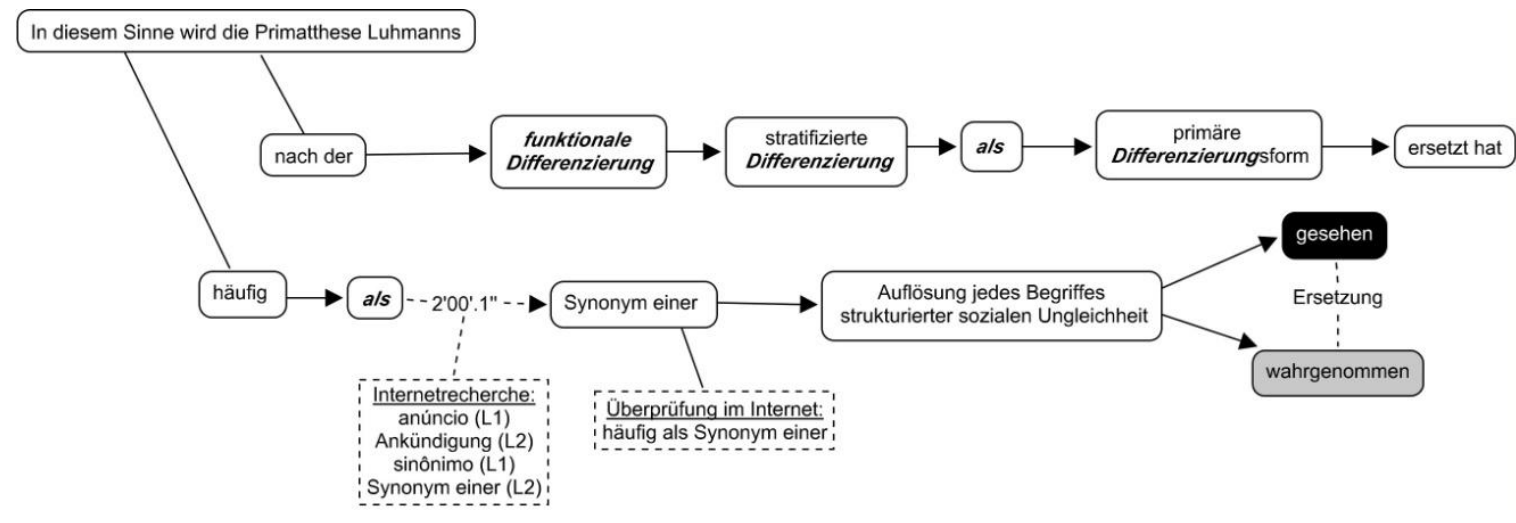

A representação do processo de construção da frase demonstra que, da esquerda para a direita, Bob produziu um trecho da sentença linearmente, com fluidez, até a abertura do segundo plano sintático com als. Aqui, a produção é interrompida por mais de dois minutos, durante os quais o autor do texto busca encontrar o lexema que exprima a relação de equivalência entre sujeito e argumento introduzida por als.

22 [W]: stratifizierte Differenzierung als primäre Differenzierungsform der mod

23 [W]: der Gesellschaft ersetzt hat, ((4s))

[G-S]: mo

$24[\mathrm{~K}]$ : googlet nach "die These, nach der" Luhmann

$25[\mathrm{~K}]$ : kehrt zum worddokument wieder

26[K]: sucht auf dem Pauker nach dem Wort ersetzen, googlet nach "stratifizierte Differenzierung ersetzt hat"

27 [W]: häufig als ((10s))

[K]: kehrt zum worddokument wieder

28 [K]: googlet nach "anúncio", korrelat, sinônimo, synonim einer

29[W]: Synonim einer ((3s)) Auflösung jedes Begriffes struktureierter sozialen Ungleichheit gesehen.

$30[\mathrm{~K}]$ : fügt Fußnote ein.

31[K]: nachdem der Text wieder gelesen wird, googlet nach "Auflösung jedes Begriffs", anschließend nach "Auflösung eines Begriffs", "des Begriffs"

$32[\mathrm{~K}]$ : kehrt zum Worddokument wieder, macht Revisionen

33 [G-S]: gesehen

[Rp]: wahrgenommen $((22 \mathrm{~s}))$ 


\section{Matias, J. - Encenação da competência lingüística em DAF}

A primeira estratégia do informante é procurar o verbete anúncio em um dicionário de tradução online, o que o leva à opção Ankündigung. O processo de busca mostra que a sequência de ativação dos itens lexicais transcorre do mais concreto, cotidiano, frequente, para o mais específico e abstrato, o qual finalmente é sancionado. Naturalmente, em termos semânticos, pode-se especular que o informante, na verdade, reconcepcionalizou sua mensagem, se considerarmos que, entre anúncio e sinônimo, há uma perceptível diferença de significado. Nesse caso, pelo fato de o autor do texto conscientemente rejeitar uma alternativa lexicalmente mais comum, em detrimento de uma mais específica, enxergamos um modo de encenação da competência linguística. Pois o receptor do texto - a menos que tenha contato com os dados dessa pesquisa jamais saberá das opções comuns, que permearam a processo de redação. Ou seja, são estratégias que o autor utiliza para complicar o seu texto.

A mesma lógica aplica-se à substituição do verbo sehen, acentuadamente comum, por wahrnehmen, que, apesar de ser menos comum que sehen no contexto de situação, é mais genérico, praticamente um superordenado. Como no caso de anúncio e sinônimo, aqui, a sequência do acesso lexical se dá do mais concreto para o mais abstracto.

A substituição do verbo sehen e a dificuldade em preencher a posição remática manifesta-se na produção de outros autores de texto, como vemos no segundo caso.

\section{Caso 2}

Häufig wird das Thema Jugendlichen mit einem Migrationshintergrund und ihrer Integration innerhalb der deutschen Gesellschaft als ungelung erwähnt.

Esta é a frase de abertura do resumo da informante Dani. Nela, a autora exprime um julgamento distanciado e modalizado com relação ao núcleo proposicional através do emprego do als predicativo complementando o verbo erwähnen. Comparado à sentença produzida por Bob, a oração de Dani, devido à parataxe, é menos complexa ${ }^{7}$, mas não deixa de atender às exigências linguístico-textuais

\footnotetext{
${ }^{7}$ ela poderia p.e. ter elaborado um grupo nominal complexo como "Die Integration Von Jungendlichen mit migrationshintergrund in der deutschen Gesellschaft"
} 
Matias, J. - Encenação da competência lingüística em DAF

Chama a atenção o adjetivo ungelung, utilizado como predicado, o qual claramente é uma palavra cunhada pela informante, não possuindo, portanto, nenhum significado em língua alemã. Ou seja, aqui, o problema reside exatamente na predicação que encerra o julgamento expresso pelo uso de als. A localização do elemento problemático, a posição remática, coincide com os dados processuais de Bob. Com efeito, a representação gráfica da formulação de Dani revela dificuldades no acesso ao verbo:

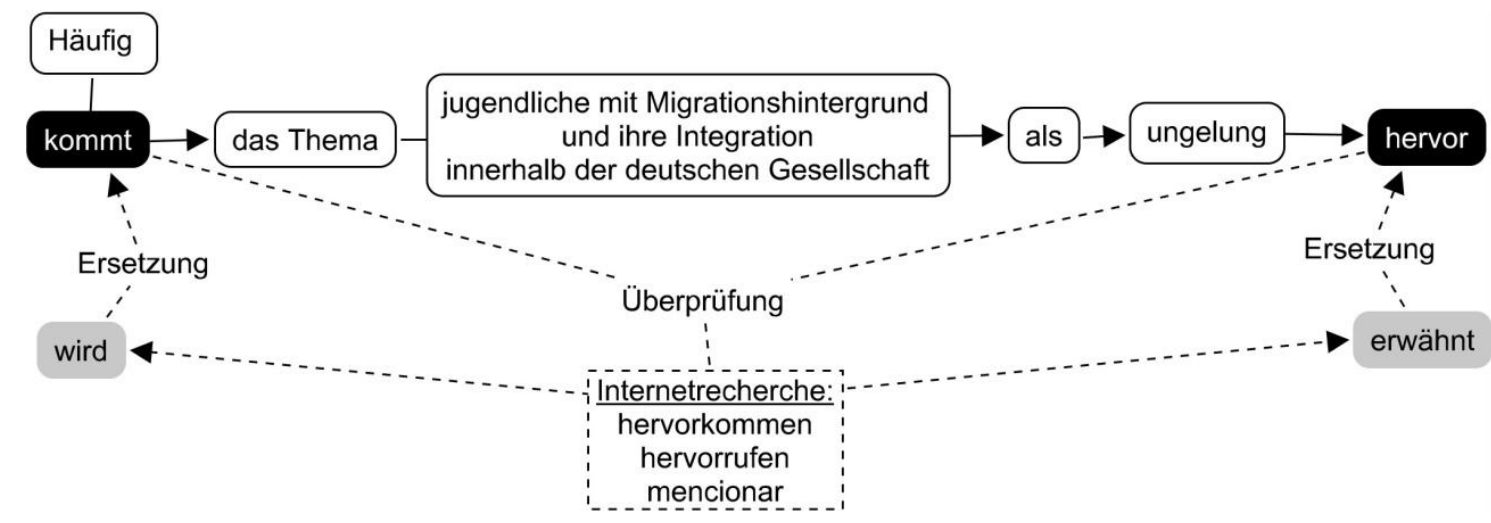

$38[\mathrm{~W}]: \bullet \cdot$ ihre Integration innerhalb der deutschen Gesellschaft als • 39[W]: ungelunghervor.

[L-S] : als ungelung?

40 [L-S] : •nee. hervorkommen ((10s)) o que? não existe essa palavra?

$[\mathrm{K}]$ : schlägt nach dem Verb hervorkommen im Pauker nach. Liest auf dem linken Rand das Verb "hervorrufen" und klickt darauf. Anschließend sucht sie nach dem Wort "mencionar".

41[G-S] : kommt...hervor

$[\mathrm{Rp}]$ : wird...erwähnt $[\mathrm{K}]$ : ersetzt das Verb hervorkommen für ein Passiv mit dem Verb erwähnen.

O primeiro segmento produzido por Dani foi linear e fluente. Em seguida, esse segmento-base é monitorado. Dani mostra-se insegura com o uso do verbo hervorheben, o que a leva a consultar um dicionário online. Primeiramente, ela busca formas em alemão que the pareçam apropriadas a partir do prefixo hervor (hervorkommen, hervorrufen), recorrendo, finalmente, a uma tradução, com o uso do verbo mencionar. Aqui, parece que a autora do texto fez o caminho inverso daquele realizado por Bob quando da seleção de itens lexicais. Baseando-se no critério de frequência, o uso de hervor, com base no corpus DWDS, ocorre menos do que o do verbo erwähnen. Nesse sentido, pode-se especular que, ao optar por um verbo separável com o prefixo hervor, a 


\section{Matias, J. - Encenação da competência lingüística em DAF}

informante buscasse factualmente uma expressão menos comum e que exprimisse maior tecnicidade.

Nesse exemplo, enxergamos um caso interessante de encenação: a informante utiliza corretamente a estrutura sintática e lexical, falhando, no entanto, na semântica do elemento que justamente determina a ação da linguagem. A tentativa de encenação foi, sob esse ponto de vista, mal sucedida.

\section{Caso 3}

Anfortas der Gralskönig beachtet nicht die Normen und Regel des Grals und deswegen wird er für sein unangemessenes Verhalten bestraft, ein Spiegelstrafe, die als Erinnerung seiner Sünde zu analysieren ist.

Similarmente aos exemplos anteriores, neste exemplo o preenchimento da posição remática é marcado por uma pausa. Com efeito, essa pausa aponta para a dificuldade da informante Cris em acessar na L2 um constituinte do complemento verbal. Esse é parte integrante do predicado, o qual especifica o núcleo nominal subdeterminado. Portanto, a pausa poderia ser vista como indiretamente motivada pela partícula als.

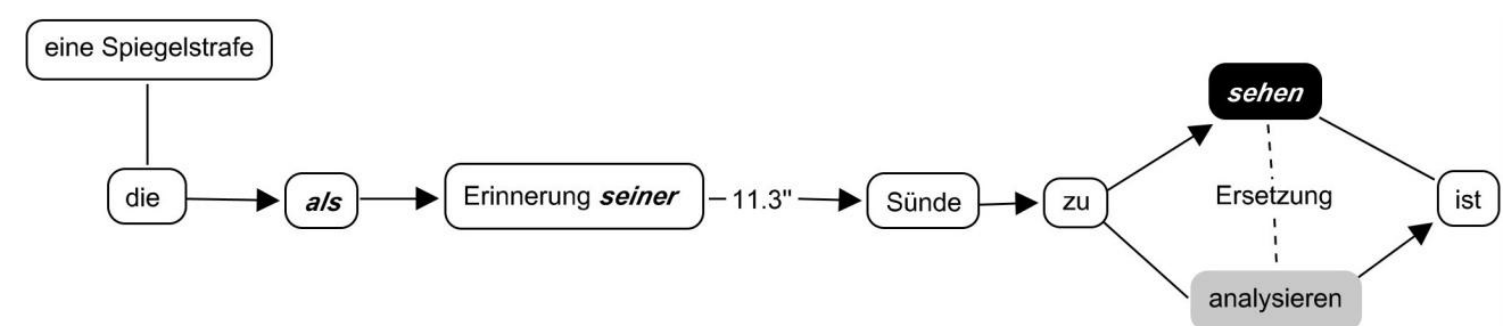

168 [Rp]: komma ein Spiegelstrafe die als Erinnerung seiner $\mathrm{uh} \bullet \bullet$ die als erinnerung seiner

169 [L-S]: Sünde?

[Rp]: Sünde

$170[$ P-L $]: \cdots$ die als Erinnerung seiner Sünde $\ldots \bullet \bullet$

171 [Rp]: zu sehen ist

[G-S]: sehen

172 [Rp]: zu analysieren ist ((14s))

Outra semelhança com o exemplo anterior é a substituição do verbo sehen por analysieren. O protocolo demonstra que sehen já estava saliente na memória de trabalho 


\section{Matias, J. - Encenação da competência lingüística em DAF}

da informante, no que esse já havia sido acessado e rejeitado em um outro momento da produção, sob o argumento de que ele seria "muito simples":

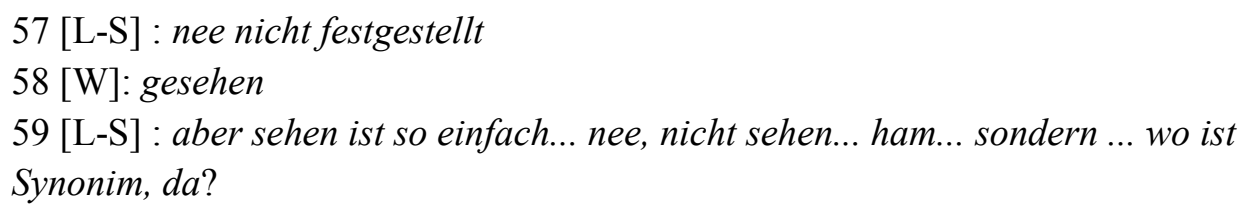

Nesse caso, o conceito de encenação linguística poderia ser aplicado, pois, embora sehen (ou mais apropriadamente ansehen) fosse possível dentro do respectivo contexto, a informante preferiu optar por um verbo menos comum que sehen. Decidir-se pelo verbo verstehen não foi uma tomada rápida de decisão. $\mathrm{O}$ verbo verstehen só foi ativado após a informante, durante a pausa, fornecer pistas pára-verbais de seu esforço consciente para acessar o item lexical desejado (Linha 60). A sequência do acesso lexical é semelhante à dos outros dois casos: sehen é a forma mais concreta e comum, portanto, a mais saliente; feststellen expressa uma conclusão baseada em observação, sendo menos comum que sehen, mas ainda baseado na experiência. Verstehen, por sua vez, informa ao recipiente uma ação no nível hermenêutico, e consequentemente, mais abstrata.

\footnotetext{
Alemão L1

Während die SexarbeiterinnInnen auf ihren Körper als rudimentärste Form wirtschaftlichen Kapitals zurückzugreifen gezwungen sind...

Neste trecho de oração, redigido pelo informante Karsten, o sintagma introduzido por als possui função adnominal: ele expande um conceito superordenado (Körper) e é um elemento facultativo na configuração sintática da oração. No processo de escrita dessa sentença, Karsten produziu, primeiramente com fluência, a frase: während die Sexarbeiterin ihren als, em seguida, produziu während die Sexarbeiterin auf ihren
} 
Matias, J. - Encenação da competência lingüística em DAF

Körper als, e após abrir um plano sintático com als, realizou uma pausa de 4.6 segundos.

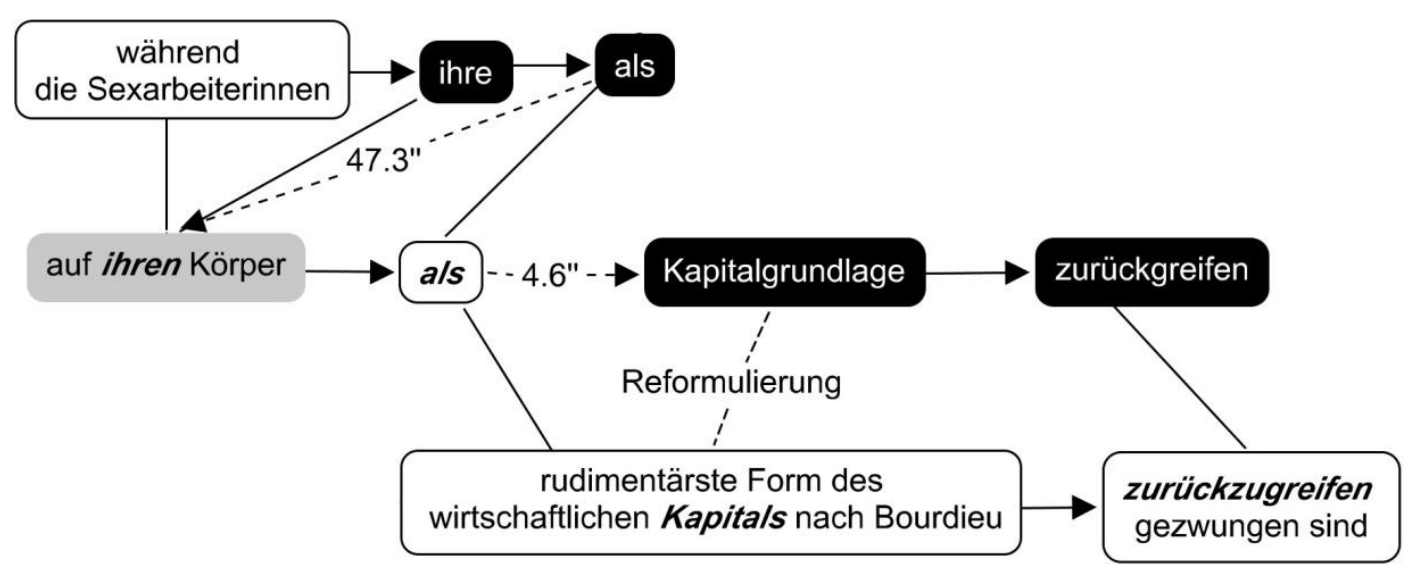

Essa pausa é um indício de que a expansão sintática aberta por als, consequentenemte a relação tema-rema a ser estabelecida, a priori não está acessível nem linguística e nem conceitualmente ao falante. Conforme demonstra o TAP, o núcleo nominal Kapital está ativado, mas a atribuição, ou seja, a caracterização ou determinação deste está ausente:

152[M-K]: ich muss da irgendetwas mit Kapital ((unverständlich)) von null an kann ich gar nichts wissen $((7 \mathrm{~s}))$ ach, das ist Mist jetzt...ist viel zu viel Text ((5s)) $[\mathrm{K}]$ : regt sich nach der Pause auf.

Após a pausa, ele formula o substantivo composto Kapitalgrundlage, o qual, em um segundo momento, é reformulado em rudimentärste Form wirtschaftlichen Kapitals nach Bourdieu.

153[W]: auf ihre Körpern als ((3s)) Kapitalgrundlage zurückgreifen [G-S]: als

154[M-K]: als...was ist denn dies, das ist nicht Kapital, das ist als rudimentär

155[Rp] : rudimentärste Form wirtschaftlichen Kapitals nach Bourdieu $156[\mathrm{G}-\mathrm{S}]:$ Kapitalgrundlage

A partir desses dados, seria plausível afirmar que aqui estamos frente a um caso de encenação linguística? Considerando-se como critério a complexidade do grupo nominal da opção sancionada, em contrapartida com o substantivo composto rejeitado, a resposta seria positiva. Um contra-argumento seria de que, neste segmento, o autor substitui um conceito por outro, se considerarmos que Kapitalgrundlage e 


\section{Matias, J. - Encenação da competência lingüística em DAF}

rudimentärste Form wirtschaftlichen Kapitals têm significados distintos. Em todo caso, aqui também a formulação do elemento referenciador exigiu o emprego de reparos.

Na produção de Karsten encontramos ainda mais um exemplo interessante na formulação de uma estrutura comparativa. No processo, após formular com relativa fluência o segmento diejenige, die mit dem Kopf arbeitet, o autor do texto, ao monitorar a superfície textual, considera o enunciado "hohl" - vago, oco. Por conseguinte, ele reformula o enunciado em diejenige, die mit Fähigkeiten witschaftet, repetindo a seqência de acesso lexical que vai do mais comum para o mais científico:

$170[\mathrm{Rp}]$ : viel größeren

$171[\mathrm{~K}]$ : setzt nach ausgesetzt fort

$172[\mathrm{P}]$ : als die $((5 \mathrm{~s}))$ jenige, die mit dem Kopf arbeitet

173 [M-K] : das klingt jetzt total hohl eh, das klingt jetzt mit dem Kopf, so ein Bullshit ((6s))

174 [L-S] : mit geistigen Fähigkeiten witschaftet

175 [P] : geistigen Fähigkeiten wirtschaftet/ das Einkommen erbringt.

\section{Conclusão}

Reconhecer contextos de encenação da competência linguística significa identificar formas de expressão, através das quais os autores crêem estar utilizando recursos linguísticos adequados e sofisticados para se apresentarem a uma comunidade discursiva na língua-alvo. Este ensaio buscou identificar alguns critérios de base textual e cognitiva que possam servir de base para uma maior elaboração do conceito de encenação da competência linguística. Um dos critérios foi a complexidade do material lingüístico produzido. Os dados sugerem que, tanto na língua estrangeira, como na língua materna, os informantes se esforçam para encontrar um modo de expressão que se distancie da linguagem comum e se aproxime da linguagem comum científica. Isso foi demonstrado a partir da sequência do acesso de itens lexicais.

Uma outra interpretação seria de que os autores buscam reprimir formas conceptualmente muito salientes, buscando, deste modo, uma variedade lexical que demonstre o seu domínio linguístico. 


\section{Matias, J. - Encenação da competência lingüística em DAF}

A encenação pode, em alguns contextos, caracterizar-se pelo uso equivocado de uma construção ou item lexical. Nesse caso, se o monitor é ativado, o elemento utilizado pode ser revisto e, em parte, modificado.

Contudo, nem todo erro é uma tentativa de encenação, assim como a encenação através da substituição de uma estrutura simples por outra complexa exige que ambas tenham significados equivalentes.

A partir de tais observações, pode-se concluir que als factualmente é um recurso linguístico efetivo para a reprodução de atos comunicativos dentro de textos acadêmicos, amplamente utilizado tanto na L1 quanto na L2. Prova disso é que, em raros exemplos do nosso corpus processual, um autor rejeita um plano sintático iniciado por als.

Um dado interessante é o fato de a produção do elemento que deve preencher a posição remática geralmente ser precedido por pausa. Nesse sentido, os dados apresentam conformidade com a análise de BÜHRIG (1996: 239) para reformulações introduzidas por also. Als marca o limite do conhecido. Assim, ele abre um plano sintático que exige o acesso de informações da memória de longo prazo, e a codificação desta informação em uma relação de equidade referencial ou de pertencimento, função, instrumento etc., o que pode exigir considerável esforço cognitivo tanto na L1 quanto na L2.

Embora a noção de encenação da competência linguística seja ainda mais complexa do que o escopo da presente contribuição, ela permite algumas reflexões didáticas para a aula de escrita em língua estrangeira. Através dessa noção, é possível sensibilizar os alunos para a diversidade de níveis estilísticos que se pode alcançar com recursos linguísticos mais ou menos complexos. A própria encenação de estilos, como numa famosa crônica de Paulo Mendes Campos, é um exercício profícuo e prazeroso que pode ser amplamente utilizado na aula de produção de texto em língua estrangeira.

\section{Referências Bibliográficas}

ANTOS, G. Jakobs, Sprachliche Inszenierungen von "Expertenschaft" am Beispiel wissenschaftlicher Abstracts. In: KNORR, D. \& MOLITOR-LÜBBERT, S. ed. Wissenschaftliche Textproduktion, Wissenschaftliche Textproduktion: mit und ohne omputer. Frankfurt a.M: Peter Lang, 1995. pp. 113-127. 


\section{Matias, J. - Encenação da competência lingüística em DAF}

ANTOS, G. Kulte, Kommunikation, Konsens-Inszenierungen. In: HABSCHEID, S. \& KNOBLOCH,

C. Einigkeitsdiskurse: zur Inszenierung von Konsens in organisationaler und öffentlicher Kommunikation. Wiesbaden : VS Verl. für Sozialwiss., 2009. pp. 117-126.

BÜHRIG, Kristin. Reformulierende Handlungen. Tübingen: Gunter Narr, 1996.

Charaudeau, P. O discurso propagandista : uma tipologia. In: Machado, I. \& Mello, R. Análises do Discurso Hoje, vol. 3. Rio de Janeiro : Nova Fronteira (Lucerna) 2010, p.57-78, acessado em 8 de outubro de 2013 no site Patrick Charaudeau - Livres, articles, publications. URL: http://www.patrick-charaudeau.com/O-discursopropagandista-uma.html

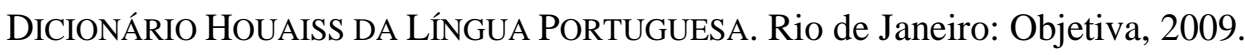

EHLICH, Konrad. Alltägliche Wissenschaftssprache. In: Informationen Deutsch als Fremdsprache 1, 1999. pp. 3-24.

EGGS, F. Die Grammatik von als und wie. Tübingen: Gunther Narr Verlag, 2006.

ENKVIST, Nils \& BJÖRKLUND, Martina. Toward a taxonomy of structure shifts. In: M. HEYDRICH, Wolfgang ed.; et. al. Connexity and coherence: analysis of text and discourse. Berlin: de Gruyter,1989. pp. 324-341.

FANDRYCH, Christian. Bilder vom wissenschaftlichen Schreiben. In: Materialien Deutsch als Fremdsprache 73, 2004. pp. 269-291.

FEHRINGER, Carol \& FRY, Christina. Frills, furbelows and activated memory: syntactically optional elements in the spontaneous language production of bilingual speakers. In: Language Sciences 29, 2007. pp. 497-511.

FlAATE, Inghild. Die als-Prädikative im Deutschen: Eine syntaktisch semantische Analyse. Tübingen: Stauffenburg, 2007.

GotTBURGSEN, A. Zur sprachlichen Inszenierung von Geschlecht - doing gender in Kontaktanzeigen. Zeitschrift für germanistische Linguistik, 1995, 23. pp. 257-283.

GRAEFEN, Gabriele. Wie formuliert man wissenschaftlich? In: Materialien Deutsch als Fremdsprache 52, 1999. pp. 222-239.

GrAEFEN, Gabriele. Aufbau idiomatischer Kenntnisse in der Fremdsprache. In: Materialien Deutsch als Fremdsprache 73, 2004. pp. 293-309.

HABSCHEID, S. \& KNOBLOCH, C. Zur Einführung in den Band. In: HABSCHEID, S. \& KNOBLOCH, C. Einigkeitsdiskurse: zur Inszenierung von Konsens in organisationaler und öffentlicher Kommunikation. Wiesbaden : VS Verl. für Sozialwiss., 2009. pp. 7-17.

Hoffmann, Ludger. Funktionale Syntax: Prinzipien und Prozeduren. In: HofFMAnN, Ludger ed. Funktionale Syntax: die Pragmatische Perspektive. Berlin u.a.: Walter de Gruyter, 2003.

KRAUSE, D. Luhmann-Lexikon. Ferdinand Enke, Stuttgart, 1996.

LAKoff, G. \& Johnson, M. Metaphors we live by. Chicago e Londres: The University of Chicago Press, 1984.

LEVELT, W. Speaking: From intention to articulation. Cambrige Mass. u.a.: MIT Press, 1993 (1a. ed. 1989).

LuHMAnN, N. Reduktion von Komplexität. In: RITTER, J. \& GRÜnDER, K. Historisches Wörterbuch der Philosophie. Vol. 8. Basel:Schwabe: 1990. p. 378.

Luhmann, N. Soziale Systeme - Grundriß einer allgemeinen Theorie. Frankfurt a. M.: Suhrkamp, 1984.

PeChMANN, Thomas. Sprachproduktion - zur Generierung komplexer Nominalphrasen. Opladen: Westdeutscher Verlag, 1994. 


\section{Matias, J. - Encenação da competência lingüística em DAF}

RoCA DE LARIOS, J.; MURPHY, L. \& MANCHÒN, R. The use of restructuring strategies in EFL writing: A study of Spanish learners of English as a foreign language. In: Journal of Second Language Writing 8, 1999. pp. 13-44.

SCHILPEROORD, Joost. It's about time: temporal aspects of cognitive processes in text production. Amsterdam: Rodopi B.V., 1996.

SWALES, J. Nonnative speaker graduate engineering students and their introductions: Global coherence and local management. In: CONNOR, U. \& JoHns, A. (ed.) Coherence in Writing: Research and Pedagogical Perspectives. Alexandria, Va. : Teachers of English to Speakers of Other Languages, 1990. pp. 187-207.

THURMAIR, Maria Vergleiche und Vergleichen: eine Studie zu Form und Funktion der Vergleichsstrukturen im Deutschen. Tübingen: Niemeyer, 2001.

YAKHONTOVA,T."Selling" or "telling"? The issue of cultural variation in research genres. FLOWERDEW, John ed. Academic Discourse. London: Longman, 2002. pp. 216-232.

WROBEL, Arne Schreiben als Handlung: Überlegungen und Untersuchungen zur Theorie der Textproduktion. Tübingen: Niemeyer, 1995.

Wrobel, Arne. Schreiben und Formulieren. Prätext als Problemindikator und Lösung. In: PERRIN, D. et. al (ed.) Schreiben. Von intuitiven zu professionellen Schreibstrategien. Opladen: Westdeutscher Verlag, 2002. pp. 20.

\section{Corpora}

Deutsche National BibliotheK Disponível em: <http://www.dnb.de/DE/Home/home_node.html > (31/08/2013)

DIGITALES WÖRTERBUCH DER DEUTSCHEN SPRACHE (DWDS) Disponível em: $<$ http://www.dwds.de/> (10/09/2013)

Recebido em 06/08/2013

aceito em 11/10/2013 